\title{
Hunger, fear and isolation: An analysis of media reports of COVID-19 related suicides in India
}

\section{Madhumitha Balaji}

Sangath, India

Vikram Patel（ $\nabla$ vikram_patel@hms.harvard.edu )

Department of Global Health and Social Medicine, Harvard Medical School, Boston, USA, and Sangath, India

\section{Research Article}

Keywords: Suicide, COVID-19, India

Posted Date: October 30th, 2020

DOl: https://doi.org/10.21203/rs.3.rs-99851/v1

License: (1) This work is licensed under a Creative Commons Attribution 4.0 International License. Read Full License 


\section{Abstract}

Purpose: India's suicide rates are among the highest in the world, and may increase further as a consequence of COVID-19. There is an urgent need to examine which pandemic related stressors may be contributing to suicide and to identify vulnerable populations to inform the deployment of suicide prevention strategies.

Methods: We identified, and conducted a thematic analysis of Internet media reports of COVID-19 related suicides in India between February 1, 2020 (2 days after the first COVID-19 case), and May 31, 2020, (the end of phase four of the nationwide lockdown).

Results: We identified 291 suicides, and observed a rise in the number reported every month. 10 pandemic stressors spanning both disease and lockdown-related factors contributed to these suicides. Economic hardship was present in a third; other notable stressors were: fear of the virus; isolation; desperation to be connected with loved ones or return home; and craving for alcohol. A range of groups seemed particularly vulnerable to these stressors including specific demographic populations (young people, men); socially disadvantaged groups (for example, migrant workers); and those with health problems and other risks (for example, persons with COVID-19 exposure).

Conclusions: COVID-19 related suicides are precipitated by social and economic adversities, mainly associated with containment strategies. Urgent action is needed to implement a nationwide suicide prevention strategy which can mitigate the impact of recognized stressors, target high-risk individuals, and offer mental health care alongside containment strategies.

\section{Introduction}

The first COVID-19 case in India was reported on January 30, 2020 and the world's most stringent lockdown was imposed on 1.3 billion people with four hours' notice on March 24, 2020. The Central Government invoked the 'Disaster Management Act 2005' [1], which included the closing of international, state and regional borders; banning of public transport; and restrictions of all movement by private individuals and businesses except for 'essential' services [2, 3, 4]. This phase lasted three weeks, and was progressively lifted until the end of May when lockdowns became locally implemented. Yet, the number of cases, and geographic spread, continue to increase across the country. As of September 7, 2020, India registered over $\mathbf{4 2 , 0 0 , 0 0 0}$ cases [5]; however, sero-surveys show that the true number of infections are tenfold or more [6].

The lockdown left tens of millions of poor urban workers with no means of livelihood and unable to return to their homes. In the absence of public transport, thousands began trudging on foot, with meagre belongings in hand, and hundreds of kilometres in the scorching summer ahead of them $[7,8]$. Several died along the way $[9,10]$. When transportation for migrants was finally reinstated, the epidemic began to spread uncontrollably in rural areas where the health care system was already stretched [11]. Non-COVID health services have been profoundly disrupted $[12,13,14]$. Millions have lost their jobs [15]. Fear has led 
to persons suspected of having COVID-19, including health care workers, facing persecution and hostility from neighbours $[16,17]$. There are reports of increases in domestic abuse $[18,19]$ and mental health problems $[20,21]$. Uncertainty remains regarding when the epidemic will be controlled, and how long these disruptions will continue. This situation is not unique to India - the UN called it a "a global mental health crisis" [22].

Can such a crisis lead to suicide to India - a country whose suicide rates are already among the highest in the world, and which was home to $1 / 3$ of all female and $1 / 4$ of all male suicides before the pandemic? [23]. Mental health problems, unemployment, and economic uncertainty - the felt impacts- are established risk factors for suicide [24], and there have been increases in suicides following other global epidemics such as the Spanish Flu (1918) [25] and SARS (2003) [26]. It is, as yet, too early to derive reliable quantitative estimates of the impact on suicide mortality due to the lack of data and with the country still gripped in a worsening epidemic. On the other hand, there has been extensive reporting of suicides in the media which offer a unique source of data to assess what pandemic-related stressors may be contributing factors and identify populations that may be vulnerable, in order to inform the dynamic deployment of suicide prevention strategies [27].

\section{Methods}

A Google advanced search was conducted to identify online media articles on "suicide" from "India", from February 1, 2020 (2 days after the first reported COVID-19 case) to May 31, 2020 (the end of the fourth, and final phase of the nationwide lockdown). This broad search was followed by a second search to identify any articles missed previously, by using key terms specifically related to the pandemic, for example, "sars-cov-2", "coronavirus", or "lockdown". Identified articles were supplemented with those from an online, public database of all deaths in India which were potentially attributable to the lockdown, to ensure that no reported suicides were missed [28].

Articles in languages other than English were translated using Google Translate. Each identified article was examined in detail, and only those pertaining to COVID-19-related suicides were included for analysis i.e., if they explicitly mentioned the pandemic, or if the suicide occurred in the context of circumstances not present before (for e.g., during "quarantine"). Excluded articles describing non-COVID suicides were checked and verified by an independent reviewer. Care was taken to avoid duplications in the identified suicides, by re-readings of all articles and constant comparisons of "new" suicides identified with those extracted previously. If there were any doubts, those persons were discarded from the list.

All included articles were imported into QDA Miner Lite (v2.0.7) [29] and analysed using thematic analysis, which involved: 1 ) reading and re-reading all; 2) coding relevant information systematically across the entire dataset; 3 ) collating codes into themes; 4) checking if the themes captured the meaning of the coded extracts, and revising them accordingly by combining, splitting or re-ordering them; 5) defining and naming the final themes; and 6) selecting data extracts that best reflected the themes. If a 
suicide had more than one stressor, it was coded under multiple themes (for example, if a person feared the virus and was under quarantine, his/her suicide was coded under both 'fear', and 'isolation'). The analysis was undertaken by MB, with steps 3 and 4 being independently reviewed by VP. Any discrepancies were resolved through discussion, and the final themes (steps 5,6 ) were constructed by both authors. Additionally, a descriptive quantitative analysis was conducted using MS Excel and SPSS 25 , to categorise all identified suicides, and generate frequencies for the pandemic-related stressors [30].

\section{Results}

The Google search identified 475 articles. 256 were excluded- 1 page "could not be found", 8 reported unclear causes of death or homicides, 27 reported suicides prior to February 2020, 149 reported nonCOVID suicides, 25 reported suicidal attempts or ideation, 36 had data from other countries, and 10 were unrelated to suicides. The remaining 219 articles, along with 151 articles from the online database, were included for analysis [Appendix Table1].

\section{COVID-19 related suicides}

These 370 articles covered 291 suicides (Appendix Table2, Table1). Information regarding gender and region were available for all, whereas information on age, and the method were available for 247 (84.9\%) and $264(90.7 \%)$ respectively. $85.9 \%$ of the suicides were by men. $47.1 \%$ occurred in persons between 20 and 39 years of age (if one includes the 10 "youth", this figure is $50.5 \%$ ). There were eight couples. Hanging was the most common method (63.2\%). Two states, Uttar Pradesh and Maharashtra, accounted for the highest number of identified suicides; both States are also among the worst affected by COVID-19 [31]). The number of suicides increased over time, with the highest number and the largest percentage increase recorded in May 2020 (Figure1).

\section{Table 1: Demographic data of identified suicides}




\begin{tabular}{|c|c|c|c|}
\hline Demographic data & Categories & $\mathbf{N}$ & $\%$ \\
\hline \multirow[t]{3}{*}{ Gender } & Male & 250 & 85.9 \\
\hline & Female & 40 & 13.7 \\
\hline & Transgender & 1 & 0.3 \\
\hline \multirow[t]{7}{*}{ Age category } & $10-19$ & 15 & 5.2 \\
\hline & $20-29$ & 66 & 22.7 \\
\hline & $30-39$ & 71 & 24.4 \\
\hline & $40-49$ & 43 & 14.8 \\
\hline & $50-59$ & 31 & 10.7 \\
\hline & 60 and above & 21 & 7.2 \\
\hline & Unspecified & 44 & 15.1 \\
\hline \multirow[t]{12}{*}{ Suicide method } & Cutting & 2 & 0.7 \\
\hline & Drowning & 14 & 4.8 \\
\hline & Drug overdose & 1 & 0.3 \\
\hline & Electrocution & 1 & 0.3 \\
\hline & Firearm & 1 & 0.3 \\
\hline & Hanging & 184 & 63.2 \\
\hline & Jumping & 18 & 6.2 \\
\hline & Pesticide & 14 & 4.8 \\
\hline & Poison & 12 & 4.1 \\
\hline & Railway & 6 & 2.1 \\
\hline & Self-immolation & 11 & 3.8 \\
\hline & Unspecified & 27 & 9.3 \\
\hline \multirow{6}{*}{$\begin{array}{l}\text { States/ Union Territories } \\
\text { North India }\end{array}$} & Haryana & 13 & 4.5 \\
\hline & Himachal Pradesh & 2 & 0.7 \\
\hline & Chandigarh & 2 & 0.7 \\
\hline & Punjab & 17 & 5.8 \\
\hline & Delhi & 3 & 1.0 \\
\hline & South Kashmir & 1 & 0.3 \\
\hline
\end{tabular}




\begin{tabular}{|c|c|c|c|}
\hline & Uttarakhand & 6 & 2.1 \\
\hline & Uttar Pradesh & 46 & 15.8 \\
\hline \multirow[t]{2}{*}{ North east India } & Arunachal Pradesh & 1 & 0.3 \\
\hline & Assam & 2 & 0.7 \\
\hline \multirow[t]{4}{*}{ East India } & Bihar & 8 & 2.7 \\
\hline & Jharkhand & 14 & 4.8 \\
\hline & Odisha & 7 & 2.4 \\
\hline & West Bengal & 4 & 1.4 \\
\hline \multirow[t]{2}{*}{ Central India } & Chhattisgargh & 5 & 1.7 \\
\hline & Madhya Pradesh & 4 & 1.4 \\
\hline \multirow[t]{3}{*}{ West India } & Gujarat & 27 & 9.3 \\
\hline & Rajasthan & 7 & 2.4 \\
\hline & Maharashtra & 39 & 13.4 \\
\hline \multirow[t]{6}{*}{ South India } & Kerala & 17 & 5.8 \\
\hline & Karnataka & 21 & 7.2 \\
\hline & Andhra Pradesh & 6 & 2.1 \\
\hline & Telangana & 23 & 7.9 \\
\hline & Tamil Nadu & 15 & 5.2 \\
\hline & Puducherry & 1 & 0.3 \\
\hline
\end{tabular}

\section{Pandemic-related stressors}

There were 10 pandemic-related stressors in connection to 284 suicides (Figure2). 7 suicides could not be classified.

\section{Disease-related stressors}

Fear of the virus. Several persons died by suicide, after fearing the virus. Some had tested positive shortly before, for example, Case 168 who 'was tense... went into depression'. (The Indian Express, 10.05.2020). Others feared contracting the virus, or perceived they had been infected, despite reassurances or evidences to the contrary. For example, Case 1 'started panicking when his cold, cough and fever did not subside even after taking medicines'; his son said, "even the other villagers told him that if he really had coronavirus, the doctors would have quarantined him... (but) my father was worried that the virus would 
spread to us. He hanged himself to save us" (Hindustan Times, 12.02.2020). Some who underwent testing panicked before receiving their results, for example, Case 2. Others feared for their loved ones; for example, Case 282 'set herself ablaze fearing her husband who works abroad was affected with COVID19' (Mathrubhumi, 31.05.2020).

Isolation: Many suicides occurred during quarantine or shortly after, in those testing positive or "suspected" of having COVID-19 and/or who had travelled recently. Excerpts indicate that this experience may have cut off sources of support, and led to loneliness and rumination, especially for those worried about the virus or the lockdown. For example, Case 75 who was admitted to an isolation ward hanged himself 'out of frustration and loneliness' (Pune Mirror, 11.04.2020); Case 41 who had escaped from a quarantine centre to meet his family had 'started panicking... despite repeated attempts by officials to make him understand that it was just a precautionary measure' (Hindustan Times, 02.04.2020); and Case 254 who was quarantined at home had been 'worried as he had no money left' (News18, 22.05.2020). Some persons voluntarily secluded themselves to prevent spreading the infection to others, for example Case 112 (OpIndia, 22.04.2020), whereas others were forced into isolation by their families; for example, Case 20 who returned to India from Maldives, had gone into depression after his parents and elder brother refused to let him into the house' (The Times of India, 28.03.2020).

Discrimination and rejection. Some persons who returned home, or had symptoms were forced by their local community to get tested or pestered to vacate their accommodation. For example, Case 45 ' $k i l l e d$ himself after people in the neighbourhood insisted that he cannot continue to live there since he was a "corona patient". [A friend said] "When he kept coughing, the neighbours informed the police who took him to a hospital for testing". (Livemint, 14.04.2020). Their family members also faced harassment. For example, a relative of Case 63 (who had 'admitted himself in the hospital as per the wishes of villagers') said, 'People were not buying milk from us. It was the only source of income' (The New Indian Express, 05.04.2020). In another instance, a man who was quarantined after returning to village, and his wife (Cases 103,104$)$ died by suicide after he 'had been prevented from going home... although he had no symptoms' and 'some villagers had been mounting pressure on __ [wife] to leave the village over suspicions that her husband had contracted the disease'. (The Telegraph, 17.04.2020). Some persons were rejected by their own families. For example, Case 221 who had returned home was 'kept in a separate room... his wife looked at him through the window, but did not go near... because of fear of Corona... (his) loneliness was irritating him... repeatedly begged his wife to come to him. But she did not listen.... (he) was so hurt that he hanged himself' (News Nation TV, 15.05.2020). In one instance, Case 208, a medical supervisor, elaborated in his suicide note about how 'he was harassed and pressurised by the locals asking him not to allow COVID-19 swab test centre' (Mumbai Mirror, 14.05.2020).

Lockdown-related stressors

Economic hardship. Several individuals experienced economic hardships; these included threats to or loss of livelihood; reduced or no income; difficulty supporting family; going into or difficulty paying off debt; and acute impoverishment. For example, Case 217 'slipped into depression' after his employer 
'refused to help him financially and didn't even give him salary... had borrowed money to meet the household expenditure during the lockdown and the lenders were asking him to return their money' (The Tribune, 16.05.2020). A policeman investigating Case 182, reported, "When we visited their tin-shed home, the small room had barely anything. Even the plastic bottles were empty. They had neither food grains nor pulses nor anything else left to eat. They were drinking only water. They were crying because of starvation and asking their elder sister [case] to give them food. The girl's father was a daily-wager. Since the lockdown, he had no work. The neighbours gave them food, but she was ashamed of her plight and was humiliated by the fact that she had to beg every day" (The New Indian Express, 12.05.2020). Problems compounded, and some persons saw no way out. Case 231, for example, wrote, "I continue to suffer without work and do not have money even for food, but my landlord is demanding room rent. He is harassing me every day and I cannot take it anymore" The Logical Indian (20.05.2020).

Desperation to be connected with loved ones or return home. Social distancing measures and travel restrictions separated people from their loved ones. For example, Case 199, a young housemaid, was 'disheartened that she was unable to go home... her sister had given birth to a child and (she) was apparently upset by her inability to pay a visit' (Sakshi, 13.05.2020); and Case 72 'was missing his wife who had gone to visit her parents, and couldn't move back' (Jagran, 09.04.2020). Migrant workers who had lost their livelihood were especially desperate to return to their hometowns. Case 167 'had run out of food and money several days before... not once but twice he had managed to book train tickets to his hometown... but both times, it had been cancelled'. His family reported him to be "scared and restless, just wanted to go home... thought he will never be able to go back" and so "depressed" that "he even planned to walk back home". They said that the "uncertainty killed him" (The Wire, 13.05.2020). Case 128, who walked from Hyderabad, where he worked, to his home in Maharashtra's Gondia district (650 km away) hung himself on a tree about $160 \mathrm{~km}$ from home, as he 'lost his will to complete the remaining part of the journey' (The Indian Express, 02.05.2020). Case 152 'hurled himself in front of a goods train' after being 'overwhelmed with depression after missing the only special train that would have taken him home' (The Times of India, 09.05.2020).

Craving for alcohol: Liquor stores were shut during the first 40 days, as alcohol was not an 'essential' commodity. This resulted in suicides by 'addicts' experiencing craving and withdrawal symptoms. For example, Case 39 was 'visibly depressed' (Telangana Today, 01.04.2020) and Case 13 'had turned violent' (Asianet News, 27.03.2020). Such suicides were observed mainly in the Southern States [Table 1], which account for over $40 \%$ of India's alcohol consumption.

Domestic disputes. Some had argued with their family shortly before they died. In a few cases, the arguments were related to disobedience of lockdown rules or behavioural changes following the lockdown; for example, Case 136's was 'angered' after his 'father reprimanded him for repeatedly going to see his girlfriend outside the house' (Navbharat Times, 02.05.2020), and Case 113's 'had started playing PUBG [online game] regularly... [was] furious at being scolded by his family members for playing the game for several hours' (Hindustan Times, 26.04.2020). Lockdown-induced financial problems also led to quarrels; in one instance involving a married couple (Cases 137 and 138), the policeman said "[Wife] had 
taken 5 lakhs as loan from a local committee for hiring a truck for their livelihood. She used to repay the instalment to the committee with the income from the truck... (but) the amount of loan accumulated as plying of vehicles was stopped. On the other hand, the lenders started pressurising her for early payment. The non-payment of loan led to dispute between the husband and the wife" (The Times of India, 04.05.2020).

In two particularly disturbing incidents, men murdered their families, and then killed themselves. According to Case 56's daughter, "They [parents] could not bear being with each other and were frustrated to be together 24 hours. They were having regular quarrels since last ten days and had even started hitting each other. Today, they had been fighting since morning. In the evening, my mother said something and my father rushed to the kitchen in rage. He repeatedly hit her and she died" (The Week, 03.04.2020). Case 239 'murdered his three children and hanged himself... (was) already at home, couldn't land employment... [and] had been fighting frequently with _ [wife]... after she chided him for not looking hard enough for a job' (The Times of India, 19.05.2020).

Aspirational disappointments. For some people, the lockdown meant a delay or a failure in achieving major aspirations related to relationships or work, and the loss of their life's dreams and efforts. For example, teenagers Cases 67 and 68, 'took the step as their families didn't approve of their relationship and they couldn't flee home due to the lockdown' (Outlook, 07.04.2020); Case 124 'was depressed over the uncertainty about her foreign study plans due to the lockdown' (The Times of India, 01.05.2020); and Case 266 (an actress) 'wrote in a suicide note that she couldn't live with "broken dreams"' (Hindustan Times, 27.05.2020). Six persons committed suicide following postponement of their engagement or wedding. Case 178 for example was 'quite upset' when the nationwide lockdown was first implemented, as 'after a very long search for a suitable life partner, [she] was finally going to get engaged'. When the lockdown continued, she 'could not handle it anymore' (Ahmedabad Mirror, 13.05.2020).

Restrictions to behaviour: Staying indoors, and the resulting behavioural restrictions triggered some suicides. For example, Case 268 'wasn't allowed to step outside the house... used to go cycling and playing in the park every evening.... before killing himself, he had spoken to a friend on WhatsApp about being bored' (Mumbai Mirror, 29.05.2020); and Case 263 'had been suffering from depression ever since he was unable to go for a morning walk' (The Times of India, 24.05.2020).

Police violence and harassment. Some persons who had broken quarantine or lockdown rules were harassed or beaten by police officials, and were upset and humiliated. For example, Case 44, who had left the quarantine centre to help his sister-in-law said that a 'constable beat me up severely'. In an audio clip he released to the public, he talked about his trousers being 'stained in blood' and said 'I don't want to live now. Because of him [constable], I am killing myself'. His brother confirmed this, and also said that the Police had 'shot a video of the incident to shame him' (The Wire, 13.04.2020). Similarly, Case 60 who had travelled to his native district on a bicycle, was 'arrested' by the Police, 'they released him.... (but the) vehicle remained in police custody'. He made a video in which he says, '(The) Police... are responsible for my death' (Newsd, 03.04.2020). 


\section{Vulnerable groups}

These included:

Demographic populations: In general, young people were affected [Table1]. Notably, all aspirational disappointments were only seen in persons 30 years or younger. Case 166, for example, had been disturbed over the delay in his exams... was insecure that he might not get employed... wanted to give her (mother) his first salary' (Mirror Now Digital, 12.05.2020). Men were particularly hit by economic downturns, especially if they were the breadwinners for large families, and caring for dependents. For example, Case 141 was neither 'able to buy medicines for his bedridden father suffering from paralysis' nor 'able to pay his younger brother's tuition fee' (Odisha Bytes, 06.05.2020) and Case 82 'was under tremendous pressure to manage his family of nine members after losing his only source of livelihood' (NewsClick, 13.04.2020).

Socially disadvantaged groups: Those already poor, or in debt were affected by the lockdown. Case 281, a 'sacked hotel clerk' left behind a suicide note that said, 'I am committing suicide because of poverty and unemployment' (The Telegraph, 31.05.2020), and Case 180, an employee in a milk dairy, who was 'under pressure from private financier'said, "I am being threatened that if I don't pay money in two days then they will kill me" (The Times of India, 12.05.2020). Daily wage labourers, those who owned or operated small business, and persons employed in non-essential businesses were also affected. For example, Case 171 , an auto rickshaw driver committed suicide 'when he realised he wouldn't be able to pay instalments of the loan he had taken to buy an auto.... the vehicle has been lying idle since the lockdown started' (Mumbai Mirror, 15.05.2020); and Case 115, who worked as a gardener for a private hotel 'was told his services were not needed' (The Telegraph, 23.04.2020). Farmers were another group. For example, Case 197 'suffered loss' as 'he was unable to sell cucumbers he had grown on rented land' (Deccan Herald, 15.05.2020). Migrant workers experienced multiple stressors. Case 84, for example, was 'upset as he could not go home' and 'had no money to pay the room rent' (Northeast Now, 14.04.2020) and Case 245 who had returned to Bihar from Delhi 'was frustrated after being put in quarantine for the second time as he was sent to a quarantine centre in Delhi as well' (The New Indian Express (21.05.2020).

Some persons had had recent losses or ongoing interpersonal stressors. For example, Case 256's father 'died due to lack of treatment'during the lockdown (Satya Hindi, 23.05.2020), and Case 122's husband and in-laws 'were reportedly harassing her family to fulfil their dowry demands' (The New Indian Express, 30.04.2020). Some persons had no family, were separated from their spouses, or living alone. For example, Case 12 who believed he was infected was 'separated'from his wife (The Federal, 27.03.2020); and Case 291's 'parents had died long ago and he was living alone and had no money to buy ration (food)' (Deccan Chronicle, 28.05.2020).

Persons with health problems or risks: Persons testing positive, showing flu symptoms and/or awaiting test results, or those having ill friends or relatives were vulnerable to fear. For example, Case 134 who had 'fever and difficulty in breathing', 'was under acute depression as he feared having contracted the deadly COVID-19' (The New Indian Express, 03.05.2020), and Case 146 was in 'a state of panic following 
detection of coronavirus cases in the village' (Newsd, 07.05.2020). Some persons were from COVID-19 'hotspots', for example, Case 83 from Uttar Pradesh; Case 98 from Mumbai; and Cases 272 and 273, from Tamil Nadu. Four persons had been involved in COVID-19 management efforts, and their suicides were connected to stressors related to these efforts. For example, Case 51, a disaster management officer had been 'afraid that she could infect her son'(Hindustan Times, 05.04.2020), and Case 133, a medical student 'was attending to coronavirus patients and had told her parents that she was under tremendous stress' (India Today, 01.05.2020).

Some persons had chronic physical ailments. For example, Case 121 had kidney problems (Mangalorean, 27.04.2020), Case 183 had lung cancer (ThePrint, 13.05.2020), Case 117 'was in excruciating pain'-this was 'compounded by the unavailability of alcohol' (Mumbai Mirror, 26.04.2020), and Case 179 was HIVpositive, and committed suicide 'due to the loss of livelihood and unavailability of medicine' (Outlook, 12.05.2020). Others had mental health problems. For example, Cases 53 and 205 had been 'mentally ill' and undergoing treatment for several years (LiveHindustan, 04.02.2020, Outlook, 14.05.2020), and the two unemployed actors (Cases 216 and 266) were reportedly suffering from 'depression'. In others, the pandemic resulted in mental health problems; for example, Case 189 had 'got addicted to alcohol after his work stopped' and 'had consumed alcohol before committing suicide' (Telangana Today, 13.05.2020) and Case 118 was 'under depression due to the present lockdown'(India TV, 25.04.2020).

\section{Discussion}

We report the findings of a qualitative analysis of media reports of suicides in India in the four-month period after the first COVID-19 case, and identify several disease and lockdown stressors. Economic hardship was the most common stressor, present in over a third of suicides. These stressors disproportionately affected certain populations. We observed an increase in suicides with time, indicating a potential for further increase as the epidemic continues to unfold and economic recession bites deeper.

Our findings are comparable with reports of COVID-19 suicides from other countries. A study in Bangladesh [32] found multiple stressors related to the disease and the lockdown, for example, unemployment, fear of the virus, and family disputes, and a study from Pakistan found economic problems in many suicides [33]. Such stressors have also been observed in past epidemics. Spanish flurelated suicides have been attributed to contagion measures such as the closing of schools, religious institutions, and theatres, and the banning of social, sport and political gatherings, which resulted in decreased social integration and isolation, as well as fear in those affected and persons who had come into contact with them [25]. Similarly, social disengagement and fears of contracting the disease were seen in SARS-related suicides [34]; however, these suicides were mostly among elderly women, whereas our study indicates that young people and men are most affected. A possible explanation for this difference is the predominance of economic stressors in our sample (a consequence of the sudden lockdown, and repeated extensions), which would have had greater impact on these populations. There is 
a need for further research to estimate pandemic-related suicide risks, especially in subgroups, and specific geographical populations; make cross-cultural comparisons; examine rates over time; assess protective factors; and evaluate the effectiveness of prevention strategies.

We acknowledge the limitations of our methods which relied entirely on data from Internet media reports; thus, the identified suicides are most likely an underestimation and the narrative data subject to sensationalism and other reporting bias [35]. However, our method was the only reasonable one available, given both the confidentiality of suicide reports, and the COVID-19 situation, which made it impossible to identify and meet with families of the deceased, for psychological autopsy investigations. We minimised these limitations through a systematic search of all media articles; using data from the deceased wherever available (suicide notes, etc); and employing rigor in data extraction and analysis (using stringent inclusion criteria, and having two coders arrive at themes). Our methods are comparable with that of other studies which have used media reports to study stressors in suicide, including during the current pandemic [32 3336$]$.

Our study provides valuable insights as to what pandemic stressors may lead to suicide in India, which point to strategies for prevention - not just for COVID-19, but also future pandemics. These can target the whole population as well as high-risk groups, and include: continued government-led virus-relief efforts; accurate, non-threatening and non-stigmatising communication about COVID-19; strengthening of nonCOVID-19 health services; more mental health support, for example, crisis centres, digital interventions for building resilience, and allocations of resources towards combating long-term impact; screening for mental health problems, and provision of psycho-education and community support for symptomatic, alone and quarantined individuals, and involvement of family and general practitioners in this process; provision of psychological support for frontline workers; sensitisation of Police; etc. Pandemic control strategies must be sensitive to potential adverse impacts on mental health, and be guided by the following principles: (1) considering the pandemic as a humanitarian crisis rather than a law-and-order problem; (2) conducting a detailed assessment of policies before implementation to ensure that the needs of the most vulnerable groups are addressed in advance; (3) preparing the community with sufficient planning and time; and (4) engaging a wide range of stakeholders, including media and health communities, to build public support and trust.

\section{Declarations}

\section{Acknowledgements}

We would like to thank Arjun K Shah for reviewing the excluded articles on suicide to ensure that these were not related to COVID-19. The authors received no funding for this research.

\section{Funding}

The authors received no funding for this research. 


\section{Conflict of interest}

Vikram Patel is a co-founder of Librum, a mental health consulting firm.

\section{Availability of data and material}

All data has been made available.

\section{Ethical approval}

The manuscript does not contain clinical studies or patient data.

\section{Author contributions}

Both authors contributed to the study conception and design. Madhumitha Balaji did the data extraction and the analysis, and wrote the first draft. Vikram Patel assisted with the analysis and critically reviewed the paper. Both authors read and approved the final manuscript.

\section{References}

[1] Ministry of Law and Justice, Government of India. The Disaster Management Act 2005. Available from: https://www.ndma.gov.in/images/ndma-pdf/DM_act2005.pdf

[2] Ministry of Home Affairs, Government of India. Guidelines on the measures to be taken by the Ministries/ Departments of Government of India, State/ Union Territory Governments and State/ Union Territory Authorities for containment of COVID-19 Epidemic in the Country. 2020 March 24; Available from: www.thehindu.com/news/national/article31155941.ece/binary/HomeMinistryGuidelines.pdf

[3] Negi MS (2020 April 7). Close schools, all religious activities, extend lockdown: States tell Centre. India Today Available from: https://www.indiatoday.in/india/story/close-schools-all-religious-activities-extendlockdown-states-tell-centre-1664354-2020-04-07

[4] Ministry of Health and Family Welfare, Government of India. Containment Plan for Large Outbreaks Novel Coronavirus Disease 2019 (COVID-19). Available from: https://www.mohfw.gov.in/pdf/3ContainmentPlanforLargeOutbreaksofCOVID19Final.pdf

[5] Ministry of Health and Family Welfare, Government of India. Available from:

https://www.mohfw.gov.in

[6] Murhekar MV, Bhatnagar T, Selvaraju S, et al (2020). Prevalence of SARS-CoV-2 infection in India. Findings from the national serosurvey, May-June 2020. Indian Journal of Medial Research [Epub ahead of print]. Available from:

[7] Omar R, Jatin A, Ajeet M (2020 April 4). Migrant workers and their long march to uncertainty. Available from: https://www.thehindu.com/news/national/india-coronavirus-lockdown-migrant-workers-and-their- 
long-march-to-uncertainty/article31251952.ece

[8] Venkatraman T, Chauhan S, Dey S, Mishra R (2020 May 16). In long walk back home, migrants battle hunger, scourge of Covid-19. Hindustan Times. Available from: https://www.hindustantimes.com/indianews/in-long-walk-back-home-migrants-battle-hunger-scourge-of-disease/story-

TizRfUz69osJQ0Uqmm6jZN.html

[9] Warsi Z (2020 May 7). 42 Migrant Workers Died in Road Accidents While Trying to Return Home during Lockdown: Report. News18. Available from:

https://www.news18.com/news/india/42-migrant-workers-died-in-road-accidents-while-trying-to-return-totheir-home-states-during-lockdown-report-2609841.html

[10] Nandi S, Bhaskar U (2020 May 8). Migrants' deaths on the tracks a wake-up call for India. Livemint. Available from: https://www.livemint.com/news/india/migrants-deaths-on-the-tracks-a-wake-up-call-forindia-11588958792629.html

[11] Reuters (2020 May 26). India's Coronavirus Cases Rise as Millions of Migrants Return Home Raising Fears of Spread Through Villages. News18. Available from: https://www.news18.com/news/india/indiascoronavirus-cases-rise-as-millions-of-migrants-return-home-raising-fears-of-spread-through-villages2638083.html

[12] Rukmini S (2020 April 27). How covid-19 response disrupted health services in rural India. Livemint. Available from: https://www.livemint.com/news/india/how-covid-19-response-disrupted-health-servicesin-rural-india-11587713155817.html

[13] Shukla A (2020 April 13). Non-covid patients struggle for health services; dialysis patients worst hit. CNBCTV18. Available from:

https://www.cnbctv18.com/healthcare/non-covid-patients-struggle-for-health-services-dialysis-patientsworst-hit-5758891.htm

[14] Nagarajan R, Dhar S (2020 April 3). How Covid war is hurting India's non-Covid patients. Times of India. Available from: https://timesofindia.indiatimes.com/india/how-covid-war-is-hurting-indias-noncovid-patients/articleshow/74949121.cms

[15] Vyas M (2020 May 12). Longterm cost of lockdown. Centre for Monitoring Indian Economy. Available from: https://www.cmie.com/kommon/bin/sr.php?kall=warticle\&dt=2020-05-12\%2010:21:58\&msec=653.

[16] Javadekar P, Vaidya-Kannur H (2020 May 1). The social impact of Covid-19 on India. Sakal Times. Available from: https://www.sakaltimes.com/opinion/social-impact-covid-19-india-49313

[17] Pandey V (2020 April 3). Coronavirus: India doctors 'spat at and attacked. BBC news. Available from: https://www.bbc.com/news/world-asia-india-52151141 
[18] Ratnam D (2020 April 6). Domestic violence during Covid-19 lockdown emerges as serious concern. Hindustan Times. Available from: https://www.hindustantimes.com/india-news/domestic-violenceduring-covid-19-lockdown-emerges-as-serious-concern/story-mMRq3NnnFvOehgLOOPpe8J.html

[19] Bari P (2020 May 15). Domestic violence calls up 12 times in 5 weeks of lockdown, say Pune police. Hindustan Times. Available from: https://www.hindustantimes.com/pune-news/domestic-violence-callsup-almost-12-times-in-5-weeks-of-lockdown-pune-police/story-A01/remQ010icXqT2QQSNJ.html

[20] Roy D, Tripathy S, Kar SK, Sharma N, Verma SK, Kaushal V (2020). Study of knowledge, attitude, anxiety \& perceived mental healthcare need in Indian population during COVID-19 pandemic [published online ahead of print, 2020 Apr 8]. Asian Journal of Psychiatry 51:102083

[21] Chakraborty K, Chatterjee M (2020). Psychological impact of COVID-19 pandemic on general population in West Bengal: A cross-sectional study. Indian Journal of Psychiatry 62: 266-272.

[22] UN News (2020 May 14). UN leads call to protect most vulnerable from mental health crisis during and after COVID. Available from: https://news.un.org/en/story/2020/05/1063882

[23] India State-Level Disease Burden Initiative Suicide Collaborators (2018). Gender differentials and state variations in suicide deaths in India: The Global Burden of Disease Study 1990-2016. Lancet Public Health 3(10): e478-e489. doi:10.1016/S2468-2667(18)30138-5

[24] World Health Organization. Preventing suicide: A global imperative (2014). Available from: www.who.int/mental_health/suicide-prevention/world_report_2014/en/.

[25] Wasserman IM (1992). The impact of epidemic, war, prohibition and media on suicide: United States, 1910-1920. Suicide and Life Threatening Behaviour 22: 240-54.

[26] Chan SM, Chiu FK, Lam CW, Leung PY, Conwell Y (2006). Elderly suicide and the 2003 SARS epidemic in Hong Kong. International Journal of Geriatric Psychiatry 21(2):113-118. doi:10.1002/gps.1432.

[27] Gunnell D, Appleby L, Arensman E, et al (2020). Suicide risk and prevention during the COVID-19 pandemic. Lancet Psychiatry

[28] Aman, Sharma K, Krushna, Thejesh GN (2020). Non Virus Deaths. Database: Available from: https://thejeshgn.com/projects/covid19-india/non-virus-deaths and http://projects.datameet.org/covid19/non-virus-deaths

[29] Lewis RB and Maas SM (2007). QDA Miner 2.0: Mixed-Model Qualitative Data Analysis Software. Field Methods 19 (1): 87-108.

[30] IBM Corp. Released 2017. IBM SPSS Statistics for Windows, Version 25.0. Armonk, NY: IBM Corp. 
[31] India coronavirus cases: Top 10 states with maximum COVID-19 cases; Maharashtra worst hit. Business Today. 2020 June 11. Available from: https://www.businesstoday.in/current/economypolitics/india-coronavirus-cases-explained-top-10-states-with-maximum-covid-19cases/story/406517.html

[32] Boshra SN, Islam MM.The Status and Risk Factors of COVID-19 Related Suicides in Bangladesh (2020). Available from:

medRxiv 2020.08.11.20171272; doi: https://doi.org/10.1101/2020.08.11.20171272

[33] Mamun MA, Ullah I (2020). COVID-19 suicides in Pakistan, dying off not COVID-19 fear but poverty? The forthcoming economic challenges for a developing country. Brain, Behavior, and Immunity 87: 163166. $10.1016 /$ j.bbi.2020.05.028

[34] Yip PS, Cheung YT, Chau PH, Law YW (2010). The impact of epidemic outbreak: the case of severe acute respiratory syndrome (SARS) and suicide among older adults in Hong Kong. Crisis 31(2):86-92. doi:10.1027/0227-5910/a000015

[35] Armstrong G, Vijayakumar L, Niederkrotenthaler T, et al (2018). Assessing the quality of media reporting of suicide news in India against World Health Organization guidelines: A content analysis study of nine major newspapers in Tamil Nadu. Australian \& New Zealand Journal of Psychiatry 52: 000486741877234 . 10.1177/0004867418772343.

[36] Quarshie EN, Osafo J, Akotia CS, et al (2015). Adolescent suicide in Ghana: A content analysis of media reports, International Journal of Qualitative Studies on Health and Well-being 10: 1, 27682, DOI: 10.3402/qhw.v10.27682

\section{Figures}




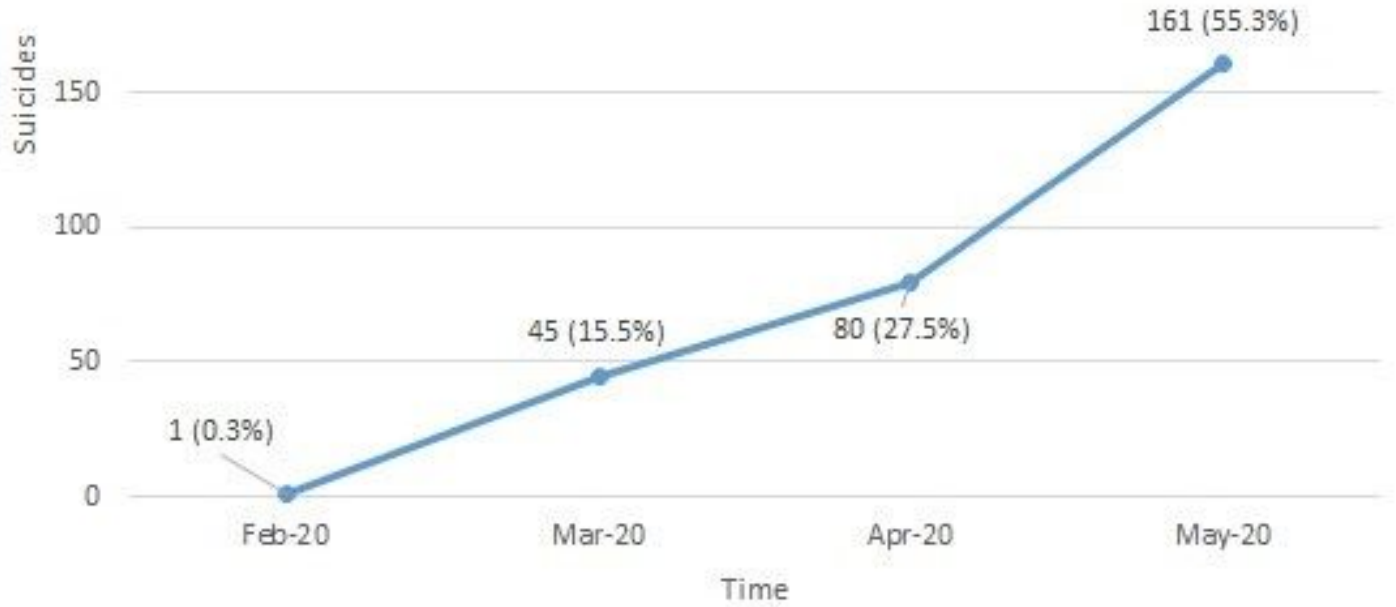

Figure 1

COVID-19 suicides identified in the study period

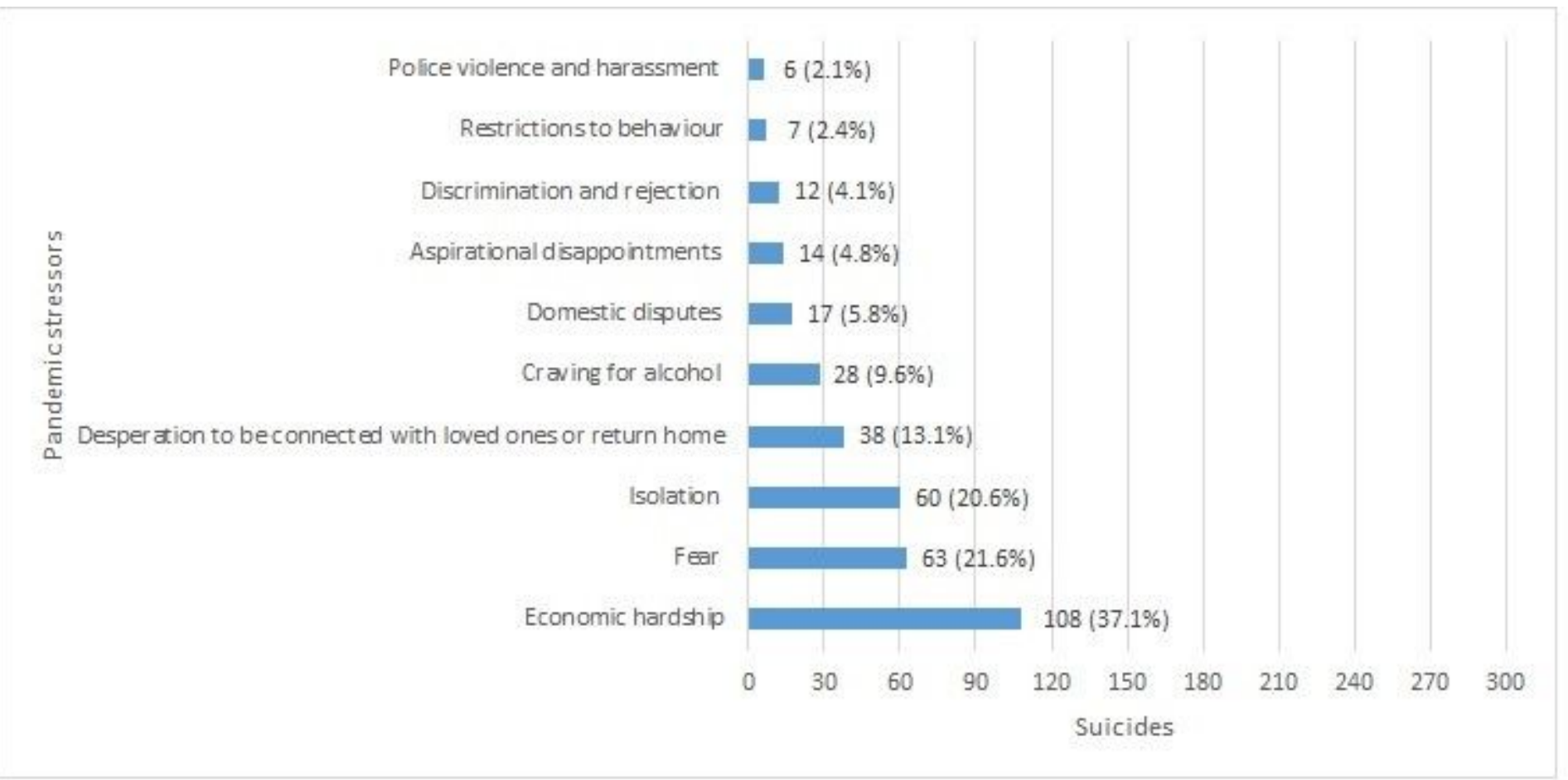

\section{Figure 2}

Pandemic stressors in identified suicides 


\section{Supplementary Files}

This is a list of supplementary files associated with this preprint. Click to download.

- AppendixTable1.pdf

- AppendixTable2.pdf 